\title{
Directionality of Education - Balanced Education and Integration of Educational Systems in the National Economy
}

\section{JEL Classification: 121}

Keywords: education, educational system, national economy, foreign languages, balanced education

\begin{abstract}
The quality of the workforce is a precondition for economic growth of a society. One of the main indicators of these preconditions is education. The effectiveness of economies of developed countries is based on the high quality of knowledge. As a resutl the quality and balanced education determines the rating of a state in the world and serves as a driving force of national economic development. The aim of the article is to identify opportunities that will allow integrating the balanced education in the educational systems of the national economy.
\end{abstract}

\section{Introduction}

The amount, structure and quality of the workforce is a precondition for economic growth of a society. One of the main indicators of these preconditions is education - a guarantor of spiritual, social and economic development of a person. All achievements of national economies of developed countries are based on the high quality of knowledge.

The development and welfare of the society depends on the growth of knowledge, on continuous education, including long-life learning or self-

(C) Copyright Institute of Economic Research \& Polish Economic Society Branch in Torun

Date of submission: February 14, 2012; date of acceptance: March 13, 2013

*Contact: antraru@inbox.lv, „Duzi”, Krimuldas novas, LV - 2144, Latvia 
education throughout a person's life, on everyday use of information technology and on the mastery of foreign languages. To a large extent, the ability of the society to absorb, accumulate and apply knowledge determines the well-being of national economy. High-quality and balanced education determines the rating of a state in the world and serves as a driving force of national economic development.

The aim of the article is to identify opportunities that will allow integrating the balanced education in the educational systems of the national economy.

The objectives of the article are:

1. to identify the connection between the level of education and the economy;

2. to determine the necessity and principles of reformation of the educational systems of post-communist countries;

3. to define general principles of regulation and planning of the systems of education in the European Union;

4. to analyze the ways that lead to balanced education;

5. to investigate the opportunities of self-education.

\section{The Connection Between the Level of Education and Economy}

There were examples when individuals did not want to study and got recognizable success without substantial education, however these cases do not show a tendency but rather exceptions. Usually, these people recognized the importance of education and developed themselves on their own.

Education is directly linked to a living standard. The highest living standard is in the countries where almost everybody can read and write (Australia, Austria, Belgium, Canada, Denmark, Finland, France, Germany, Great Britain, Island, Italy, Japan, Norway, Sweden, the New Zealand, the Netherlands, USA, etc.) (Schönherr 1998).

On the contrary, the lowest level of living standard is in such African and Asian countries as Afghanistan, Butane, Mali, Mauritania, Nigeria, and Sudan where only up to $20 \%$ of the population can read and write (Schönherr 1998).

Thus, a general conclusion is that today's national economy cannot exist without people being able to read and to write and the labour force must have a corresponding education and qualification for the economy to be successful, i.e. sufficiently developed. 
The attitude to the level of education is not the same in different countries. Even in such economically developed countries as Germany, Japan and USA there are remarkably different approaches to the level of education:

- in the USA, there is the highest level of higher education;

- in Japan, the biggest attention is paid to solid secondary education in secondary schools;

- in Germany, the biggest attention is drawn to secondary education (training, certificates, professional education).

One gets higher evaluation, i.e. higher marks for better acquired knowledge and skills when studying more consciously in the learning process. This can serve as the basis for a higher salary in the future. Thus, a student of a vocational school, college or higher school has to make a choice between his/her free time and also consumption today and his/her income and consumption in the future, i.e. after the successful studies. Of course, conscious studies can often ensure the corresponding scholarship, which can make studies or learning process easier through the effect on financial side. A good example of students who intensively use their free time for studies are the Japanese-origin students in Canadian universities. These universities have one of the shortest study year - only 8 months. The Canadians use 4 summer months to work. This is considered practice time. But the Japanese student groups organize 3 study semesters and with the inherent Japanese insistence during two years finish the three-year course with high grades. As a result, the Japanese students enter the labour market faster.

The example of Canada shows that there are opportunities of more effective exploitation of the academic year potential by individually differentiated groups of university students, alongside with the necessary amount of practice (Материалы 2005-2012).

As the economic practice worldwide shows, the connection between the level of education and the economy manifests itself most effectively in the conditions of the market economy. This relationship can be strengthened by a corresponding system of education.

\section{The Necessity to Reform the System of Education in Post-communist Countries}

The previous system of education in a range of Central and Eastern European countries was created for the collective (communistic) type of a strictly centralized economy, (Rubanovskis 2008) and it mostly did not meet the requirements of the market economy. To make the system of education in post-communist countries consistent with the requirements of the market, the appropriate reforms in the system of education are needed. 
Before that there was the socialistic thinking, which did not justify itself, as the 70 year experience of socialistic countries shows. Education can fulfill its tasks only by transforming its system, which earlier was centralized, very inert, not able to change flexibly.

Secondary education. The basis of the secondary education is formed on the German model. Unfortunately, during the socialism times this model was deformed. A large part of schoolchildren reaching 14-15 years of age further receive the professional technical secondary education: getting the theoretical training (both comprehensive and theoretical professional) in schools and practical professional training at enterprises.

The main drawbacks of this system, which the post-communist countries are now trying to overcome, are:

- early and narrow specialization;

- weak comprehensive training (education), because special subjects in this educational model push out or decrease the number of general subjects;

- inability to change the training programs quickly and thus inability to react timely on the swift changes in the labour market;

- the bad financial state of many manufacturing practice centre enterprises, or even their bankruptcy, decreases the possibilities to acquire practical professional skills and to back-up the theoretical knowledge.

To eliminate the drawbacks of the secondary education system created by socialism system the following reforms are realized:

- secondary education curricula are being worked out which students up to 16 years of age start to master. These curricula include natural sciences, technical sciences, special subjects, foreign languages and social sciences;

- secondary education curricula are being worked out intended for students over 16 years, which could help to make the choice whether to continue education in academic or professional direction. A rather new tendency is to master the technological processes within the school curricula. This activity is aimed at providing the schoolchildren with the ideas about different stages of product manufacturing processes and marketing of these processes. These curricula involve many professional subjects including business and service sectors, accenting the development of communication skills, as well as mathematics and computer sciences.

Adult education. This involves secondary schools graduates and provides them with the opportunity for:

- receiving further education:

a) professional secondary education (at vocational schools) and professional higher education (at colleges, universities and other higher schools);

b) academic education at universities and other higher schools; 
- professional training at work (at enterprises);

- extending separate courses of the professional qualification by participating in special programmes in their own country and abroad;

- training for another profession the unemployed and other interested people (Labor Markets...).

Higher education. Universities and other higher education establishments play an important role in the new conditions of the post-communist countries, undergoing a transition period to the market economy:

- they have to provide acquisition of the new knowledge and higher qualification, which are necessary in the transition to the market economy;

- they play an important role in production, propagation and popularization of scientific advances and innovations, using their research and training methods as a basis;

- they create an environment for discussions of ideas, well-founded opinions exchange, creative discussions, formation of social and cultural values that are necessary both in this radical change process and in perspective in the market economy.

In the reviewed countries region, the higher education system undergoes cardinal changes, as a result of which:

- higher education should become more available;

- possibilities to choose should expand;

- diversified financial resources should appear;

- training courses should become flexible taking into account the market conditions, for example, introducing shorter module programs.

The purpose of reformation of the system of education in post-communist countries is to create a system of education that is consistent with current conditions of the market economy. The EU has certain common regulatory acts and planning documents related to the principles of education. These principles are observed by most Western European countries.

\section{Regulation of the System of Education in the EU and Western European Practices in Education}

Latvia and other post-communist countries want to connect its future with the European Union (EU). Therefore, the EU strategy in the education and employment fields will also be binding for Latvia, which will substantially influence the labour market.

The EU internal market is defined as a territory without internal borders, where free movement of products, capital, services and people is provided. One of the prerequisites for this free movement is the recognition of professional qualification acquired in one EU state by other EU member states, 
which is most closely connected to the problems of education. EU recognition of professional qualification is regulated by three groups of directives.

General System Directive (the so-called regulated directive) consists of two smaller directives:

- First directive concerns the professions that require higher education (which is defined as at least three year of higher level studies). The main principle of this directive is that one member state must recognize the certificated professionals from other member states and should provide them employment opportunities. This directive provides a clarifying scheme as to what to do if a professional should work at a higher or lower level than it is implied by the potential of the acquired certificate.

- Second directive concerns the other professions that do not necessarily require higher education. This can be studies at a higher school for less than three year, for instance at German "Fachhochschulen". These are the two-year professional higher schools, which do not provide higher education certificate. In order to get a higher education, one must take two more years of the corresponding course at a university. Vocational schools in Latvia belong to this type of schools. If these professions are be regulated, then this second directive will cover them.

Recognition of professional qualification in separate areas is regulated by Sector Directive. This regulates the professional qualification recognition in such fields as human and veterinary medicine, pharmacy, architecture as well as separate lawyer working areas.

At the moment there is also Transition Period (Professional practice recognition system) Directive that concerns the industrial, agriculture, handicraft and separate service industry professions.

A person has the right to work in a regulated profession if $\mathrm{s} / \mathrm{he}$ possesses a document that certifies the state-recognized education and professional qualification. In case of a non-regulated profession an employer needs information that would certify the foreign employee's qualification in a country where the education was obtained, and how it corresponds to the labour qualification in the employer's country.

A certifying document in the sense how it is implied by the reviewed directives are the corresponding documents and certificates which certify the obtained education and confirm the professional training.

The world labour market tendency indicates that the demand for employees in the service industry is rising, while in the industry (production) it is decreasing.

In order to create the prognosis of labour demand in EU labour market, there was research conducted in the early 1990's in the EU and the prognosis worked out till 2010 (Table 1). The table below shows the corresponding proportions (at the time of the research) in Finland and Norway. 
The biggest percentage of the employed is expected in the consulting, social care, teaching, publishing, organizing and management fields, while the number of people working in the industry and offices will decrease.

Table1. Proportions between the main study direction in the higher schools (\%)

\begin{tabular}{|l|c|c|c|}
\hline \multicolumn{1}{|c|}{ Study courses } & Norway - 1989 & Finland - 1993 & EU - 2010 \\
\hline Humanities & 10,4 & 18,3 & 27,4 \\
\hline Law and social sciences & 35,2 & 22,8 & 23,2 \\
\hline $\begin{array}{l}\text { Mathematics, natural } \\
\text { sciences }\end{array}$ & 10,9 & 13,5 & 16,9 \\
\hline Engineering sciences & 11,0 & 20,6 & 19,0 \\
\hline Medicine & 10,3 & 7,2 & 6,3 \\
\hline Agricultural sciences & 1,1 & 2,5 & 2,2 \\
\hline Arts & 0,0 & 2,5 & 5,0 \\
\hline Teacher training & 15,1 & 10,6 & 0,0 \\
\hline Other & 6,0 & 2,0 & 0,0 \\
\hline Total & 100,0 & 100,0 & 100,0 \\
\hline
\end{tabular}

Source: Materials... (2011).

The technological advance determines the necessity of highly qualified labour that is able to apply and efficiently use the latest scientific and technical achievements, can communicate and receive information in several languages, especially this concerns inhabitants of small national states. As a striking example we may mention the Latvia model in the 20's-40's of the last century, when a person should know 3-4 languages (Latvian, German, Russian, French or English) in order to work successfully in the national economy or to do a well-paid state job. This direction governed in Latvia from the very beginning of the last century. Today's example is the Netherlands, where students usually know 4 languages (Dutch - as the mother tongue; German - as the German television and radio network cover the whole territory of Holland and people learn it from the very childhood sometimes even only from the television; English - as a the generally accepted international business language; and French - also as the diplomatic language, but a lot of technical information which can be used both for study and for further practice enters Holland in the French language). These phenomena determine the great role of the profession and academic education for the ability to be competitive on the labour market.

Now, the first foreign language in Latvian schools is taught starting from the $3^{\text {rd }}$ grade. It should be a language of some Western country and mostly it is English. Pupils begin studying the second foreign language in the 6th grade where, similarly to the first foreign language, the subject is obligatory, 
but the choice of language is free. Starting studies in the secondary school a student has a free choice to learn an additional language; however a school is not obliged to provide teaching of a third foreign language. The study of the foreign language in the basic school is always a hard aim, as often there is a lack of teachers. Last year, approximately half of the elementary school children did not study a foreign language.

The following tendencies of learning foreign languages may be observed today in non-specialized schools:

- absolute majority chooses the English language;

- many schoolchildren learn Russian in the basic school;

- the number of students studying German is higher in the higher grades;

- there is a rising interest in Nordic languages, as well as Latin and Spanish.

Last year about 7,5 thousand higher grades students studied three foreign languages, and approximately 200 - even four languages [9].

Today, the effective link between education and economy is better demonstrated by a growing balancing of education according to the demands of the national economy.

\section{The Move to a Balanced Education}

In the interests of national economy higher education should lead to a higher productivity. However, the tandem "national economy - the level of education" should be balanced. In this connection the people of the former Federal Republic of Germany acted in a traditionally reasonable way.

The studies of H. Köhler (1977) allow to calculate that from the number of 18-year-olds who have completed secondary school education, a corresponding number of higher education graduates (a group of 22-year-olds) is formed, as percentage of the total number of young people of the corresponding age group:

- in 1952 from $28,2 \%$ higher education was completed by $3,9 \%$;

- in 1962 from 34,9\% higher education was completed by $6,5 \%$;

- In 1975 from 58,5\% higher education was completed by $14,0 \%$.

Others received education and qualifications in vocational schools and in equivalent to such schools, trade schools, which since 1975 have been called vocational grammar schools and equivalent to such schools vocational technical schools and engineering schools.

The studies of the system of education of the Federal Republic of Germany, and their results by no means allow speaking about a separate German educational system, which could displace other Western European educa- 
tional systems. The German system of education is a part of the evaluation system of education of the EU.

As studies show, people in Germany do not particularly strive to obtain higher education, but they rather associate the desired level of education with labor market conditions and their individual abilities. By no means has this meant that people in Germany are not educated and intelligent. There are different kinds of courses widely popular in Germany. Short and longer educational courses have been known in Western Europe since 1875, when the first University Extension - a people's high school of a British type was opened in London. The second people's high school of the Danish type functioned before World War II in Latvia too (Latviešu... 2002). People's high schools (or people's universities) have never been granting a diploma of higher education, although certain courses (academic subjects) can be studied even at a quality of the university level. In this way the Germans obtain knowledge and expertise of high level in the areas of their interest, and develop intellectually as well. (People's universities abroad have become popular not only in Germany but also in other countries, e.g. in Norway).

The experience of Germany shows that the level of education corresponding to the relevant labor market conditions and individual abilities, i.e. the level of education that is balanced with the needs of national economy, provides a high level of development of national economy. Of course, this was not the only factor that contributed to the development of the German economy in the postwar period. But it is a factor that should be taken into account.

In essence, relying only on individual assessment, one can not evaluate the impact of education on the national economy as a whole. The fact that individuals with higher education provide higher economic returns at the individual level does not mean the same at the national level. Therefore, analyzing the impact of education on the national economy, it is necessary to analyze the link between education and growth of national economy by way of producing a per capita calculation. It will show the overall efficiency (productivity) of the country more objectively.

The effect of education on the level of the development of the national economy and welfare of the country was also studied by the British scientist A. Sweetman, who says that:

- it should be taken into account that even though this effect may be small in the short term, it may accumulate in the long run and so can generate a significant increase;

- the major problem is how to evaluate education and humanitarian capital, i.e., there is still a lack of a unified methodology (Sweetman 2012).

Although it is generally believed that education is important for both the individual and the country, attention is increasingly paid to what really is 
a contribution to education and whether the goal is outweighed by the costs. If Germany was the first that tried to balance education with the needs of national economy pragmatically, now Great Britain has started to pay a lot of attention to the problem. For instance, the Department of Education and Employment of the UK argues that there is a limit as to how many additional graduates the economy can absorb, until the productivity gains, which they create, begin to decrease.

Also, in Germany people do not always try to get the highest scientific degrees. There are two scientific degrees in Germany. For instance, next to such authoritative figure of the European scale as Wilhelm Heinrichsmeyer, born in 1935, who is Dr.hab.oec., such prominent German and EU scientists as Dr.oec. Professor Joachim Hentze, free research fellow Peter Brose and many others are successfully working.

A decent way to get a balanced education and improve it is education throughout life or life-long learning.

\section{The Potential of Life-long Learning}

Life long learning lends itself well to the system of balanced education, especially organized education.

Life-long learning or education can be realized:

- in an organized way in the form of abovementioned courses at people's universities and at different courses under the auspices of different higher education institutions, etc.

- individually, i.e. not in an organized way, but independently, which asks for personal determination, a lot of effort, self-discipline, etc.

Specializations of this kind of education are created by the demands of the labor market that correspond to the interests of the economy. One form of such education is education according to interests, which usually is realized in the form of self-education.

The education according to interests, when it is skillfully, purposefully and systematically realized, can produce very significant results. These are two examples of famous people of Latvian descent:

- Karlis Irbitis (Kärlis Irbìtis) (14.10.1904-13.10.1997) - one of the first professional aircraft designers of Europe. He graduated from the State Technical College, which was founded in 1919 with no specialisations related to aviation, then worked at Bakmanis Aircraft Factory in Riga from 1926 to 1930 and later at the State Electromechanic Factory (VEF). From 1925 to 1940 he designed 19 types of aircraft of which eight working prototypes were transferred by the Soviet authorities to the designing bureau of Andrei Tupolev in 1940. (This bureau has used many of Irbitis's mod- 
els and ideas). In the period of 1950-1970 he participated in the design of aircraft engines for "Canadair" in Montreal (Ločmelis 2012).

- Edward Liedskalninsh (Edvards Liedskalniņš) (10.08.1887-07.12.1951) had only basic school education. He inherited the knowledge of masonry and stone processing from his father, a mason and bricklayer. From 1912, he lived in Canada and the U.S.A. He devoted the last 28 years of his life to the construction of the Coral Castle in Florida City (USA, Florida). This construction surprised the world of science, which has not yet been able to discover the keys to many secrets that Liedskalninsh used in its creation. This castle is impressive - more than a kilometer in width, with the weight of masonry structures up to 58 tons, total weight of the stone blocks - more than 1,100 tons. During three years he moved all this mass of stone blocks to a distance of $16 \mathrm{~km}$, using the chassis of an old freight car. At the sites, he moved the huge stones, using only his own hands and a couple of insignificant tools. He did all operations alone, without the presence and assistance of any other helpers. Moreover, he absolutely accurately placed the blocks and calculated the weight of the structure. Thus, in order to open and close the three-and nine-ton gates, no application of serious physical strength was necessary. During that time, E.Liedskalninsh subjected himself to a strict regime - he worked 6 days a week and dedicated some of that time to tourists, and one day a week was devoted to reading books, i.e., to self-education. As a result, he obtained a good knowledge of astronomy, physics, engineering sciences, and history, which he applied to the construction of the Coral Castle. This is a good model for continuous education or life long learning, although today we understand the continuous education as a continuous replenishment of already attained educational achievement. The education received in that way is not as low as basic, but much higher, closer to the standards of higher education.

The size of the structure of the castle built by E. Liedskalninsh is compared to the construction of ancient pyramids. Besides that, he invented a power generator, constructed a radio apparatus, and in 1945 published an interesting scientific article on the magnetic flows in a scientific journal (it is believed that he used the magnetic flows for horizontal, and especially vertical movement of heavy stone blocks) (Stavro 2005).

In 1984 the Coral Castle was included in the national Register of historic monuments of the USA.

These two examples characterize the two goals of self-education:

1. The purpose of self-education coincides with the applied interests of the economy (example of K. Irbitis). Such cases are quite common in the world practice, e.g. Bill Gates, who dropped from Harvard University af- 
ter the second year of studies, and dedicated himself fully to the development of his idea.

2. The purpose of self-education may appear as a hobby (example of E.Liedskalninsh) and may not have the short term returns for the national economy. However, there may be long term returns important even for fundamental science. In this case, it is possible that the author may not fully disclose his findings and discoveries. Even the famous Leonardo da Vinci did not reveal all his discoveries to the public.

\section{Conclusions}

Modern economy cannot exist without people who are literate, and to make the economy sufficiently developed, the labor force should be appropriately educated and qualified.

The attitude to the level of education is not the same in different countries. Even in such economically developed countries as Germany, Japan and the USA there are remarkably different approaches to the level of education:

- in USA, there is the highest level of higher education;

- in Japan, the biggest attention is paid to solid secondary education in secondary schools;

- in Germany, the biggest attention is drawn to secondary education (training, certificates, professional education).

Post-communist countries that have the Soviet educational system do not meet the requirements of the market economy, including its thinking. Therefore, the educational system should be overwritten and these changes apply to the secondary, adult and higher education. The educational system of these countries should be transformed according to the EU General Scheme Directive and Professional Practice Recognition System.

Despite the fact that school age youth understands the value of language knowledge at the labour market (many students study 3-4 foreign languages), Latvia has to draw more attention to teaching foreign languages, as due to the lack of language specialists schoolchildren often are deprived of the opportunity, for example about a half of the elementary school children do not study any foreign language.

In Latvia, the system of education complies with EU requirements and practices, including the mastery of foreign languages.

Based only on the individual assessment, one cannot evaluate the impact of education on the national economy as a whole. The fact that individuals with higher education produce higher economic returns at the individual level does not mean the same at the national level. Therefore, analyzing the impact of education on the national economy, it is necessary to analyze the 
link between education and the growth of national economy, by way of producing a per capita calculation.

Although, in general, it is believed that education is important for both the individual and for the country, attention is beginning to be paid to what really is a contribution of education and whether the gains are outweighed by the costs.

Life long education is a necessary means of balancing the system of education with the national economy.

If an individual has sufficient quality indicators such as determination, perseverance, self discipline, etc., then such a person has a high potential for targeted self-education, including the mastery of languages as an integral part of education throughout life.

\section{References}

Köhler H. (1977), Der relative Schul- und Hochschulbesuch in der Bundesrepublik Deutschland 1952-1975. unveröffentlichtes Arbeitspapier, Marx-Plank-Institut für Bildungsforschung. Berlin, Dezember.

Latviešu konversācijas vārdnīca. 21.sējums (2002), Rīga, Antēra, faksimilizdevums. Labor Markets and Social Policy in Central and Eastern Europe N. Barr (ed.).

Ločmelis J. (2012), Latviešu aviokonstruktoram Kārlim Irbītim - 100, http://www.sakaru-pasaule.lv/main.php3?sub=view\&RID=1046 (15.07.2012).

Rubanovskis A. (2008), Mikroekonomikas teorijas pamati, I dal̦a. Rīga.

Schönherr G. (1998), Volkswirtschaft und Betriebswirtschaft. Bertelsmann Lexikon Verlag, GmbH. Güterslohn München.

Stavro A. (2005), Korallı pils. Lauku Avīze, Rīga.

Sweetman A. (2012), Working Smarter: Education and Productivity, http://www.csls.ca/repsp/2/arthursweetman.pdf (30.06.2012).

Materials of the Ministry of Education and Science (2011), Riga. Материалы Всемирного банка в Латвии (2005-2011). 